\title{
EXPERIMENTAL USE OF WATER HYACINTH (EICHHORNIA CRASSIPES) WETLAND FOR TREATING FLOWING WATERS IN AN URBAN PARK IN BRAZIL
}

\author{
MASCARENHAS, L.C.* \& MÉLLO, JR, A.V. \\ Escola Politécnica da Universidade de São Paulo \\ *Corresponding author: luti.mascarenhas@gmail.com
}

\begin{abstract}
Mascarenhas, L.C. \& Méllo, Jr, A.V., (2016). Experimental use of water hyacinth (Eichhornia crassipes) wetland for treating flowing waters in an urban park in Brazil. Braz. J. Aquat. Sci. Technol. 20(2). elSSN 1983-9057. DOI: 10.14210/ bjast.v20n2. This study tested water treatment wetlands in an urban park located in São Paulo, Brazil. Eichhornia crassipes (water hyacinth) was introduced into two creeks inside the park, to assess the efficacy of wetlands in treating flowing waters. Higher removals were obtained in Total Suspended Solids, Turbidity and Color (maximum removal > 70\%); Total Kjeldahl Nitrogen, Total Phosphorus and Fecal Coliforms had satisfactory removals (maximum removal $>50 \%$ ). Organic matter (measured as BOD) presented low removals and Dissolved Oxygen was consumed, indicating that aerobic processes occurred. Despite the experiment's difficulties and results' variance, the study shows that water hyacinth has potential to treat flowing water, especially when there's an urgent need for meeting sanitary and aesthetical standards in urban parks.
\end{abstract}

Keywords: Water quality, Constructed wetlands, Water treatment, Water pollution, Phytotechnologies.

\section{INTRODUCTION}

The growth of urbanized areas directly impacts the use of water resources. The city of São Paulo has faced a fast population growth, which led to an extremely dense land use. Such disorganized urban expansion speeds up environmental degradation by increasing riverside occupation which causes untreated domestic sewage discharges, solid waste and urban run-off in water courses (Silva \& Porto, 2003). A technique of great acceptance is constructed wetlands, which is the use of specific plants that remove nutrients from contaminated water in order to grow (Shutes, 2001). This technology mimics natural ecosystems, where biological activity and organic matter degradation processes occur. The treatment involves vegetation, soil and microorganisms in an integrated manner. Welsch et al. (1995) have verified that the physical-chemical and biological processes of natural wetlands are influenced by aerobic, anaerobic and facultative bacteria. These processes usually occur in the rhizosphere, where pollutants interact with plants, soil and microbes (Stottmeister, 2003). Those mechanical and biological processes remove suspended solids from the water, diminishing turbidity. Main pollutants that can be removed by existent processes in wetlands are: suspended solids, organic matter, phosphorus, nitrogen, soluble metals and pathogens (Campbell \& Ogden, 1999). Removal efficiencies usually achieved are greater than $90 \%$ for pathogens, $80 \%$ for suspended solids and organic matter, and $60 \%$ for nutrients (Shutes, 2001; Kivaisi, 2001). In addition to water quality improvement, its aesthetical and environmental value is very positive, since wetlands can compose gardens and shelter wildlife (Brix, 1997).

Adapted plants used in constructed wetlands are hydrophyte macrophytes that present morphological and physiological adaptations that allow survival in water-saturated environments (Monteiro, 2009). Macrophytes have large capability in decomposing and transforming organic matter and other substances (Brix, 1997). Its main role in wetlands is supplying oxygen and surfaces for biofilm growth, as well as consuming nutrients from polluted water. Nitrogen and phosphorus consumption by most important wetland macrophyte species was presented by Kivaisi (2001): Eichhornia crassipes (Mart. (Solms), 1883) is the biggest phosphorus consumer (350kg P.ha- ${ }^{-1}$.year ${ }^{-1}$ ) and the second biggest nitrogen consumer $(2400 \mathrm{~kg} \mathrm{~N}$.ha-1. year $\left.{ }^{-1}\right)$. At the same time, water hyacinth has shown an accelerated development, having the ability to double its population in only six days (Dhote, 2009).

This study had the purpose of testing a low cost and low landscape impact technology: the use of treatment wetlands in flowing waters. Considering that Tizo park, where the experiment was held, will soon receive visitors, the need to achieve satisfactory sanitary conditions is imminent. Financial resources are scarce and restrict the use of sophisticated technologies. The fact that water bodies are in a natural environment protected by law also makes it impossible to install structures that alter the natural landscape, even if for sanitary purposes. Then, it was sought to test wetlands treatment efficacy on two creeks in the park, seeking 
evidence that wetlands can also be used on water courses as an alternative to urban parks.

\section{MATERIALS AND METHODS}

Two experiments were developed at Tizo Urban Park, located in São Paulo, Brazil. Tizo Park possesses 130 hectares of preserved rainforest. Due to the discontinuous urbanization process of the surroundings, the area is subject to environmental impacts, such as solid waste, debris and sewage disposal, coming from houses and slums in the neighborhood (Costa, 2006).

The extremely urbanized Itaim Creek's sub basin was studied. Two creeks from the park received the experiments, populated with Eichhornia crassipes (water hyacinth). It is a species highly resistant to polluted waters and water quality variations, and for this reason, reproduces quickly when it finds sufficient nutrients (Penfound \& Earle, 1948).

The first experiment was developed on Itaim Creek (Creek \#01) between September and December, 2012. Around 500 young plants were allocated on a portion of Itaim Creek of approximately $1 \mathrm{~m} \times 10 \mathrm{~m}$, in a section characterized by steep slopes, high solar radiance and big flow variation in rainy periods. The extent of the first experiment can be seen on Figure 1. The second experiment took place on a small tributary from Itaim Creek (Creek \#02), from April to July, 2013, using about 50 adult specimens of water hyacinth placed in a tributary channel of Itaim Creek. It had approximately the same size of the first experiment, and it was characterized by slow flows, lower solar radiance and domestic sewage inflow from surrounding areas.

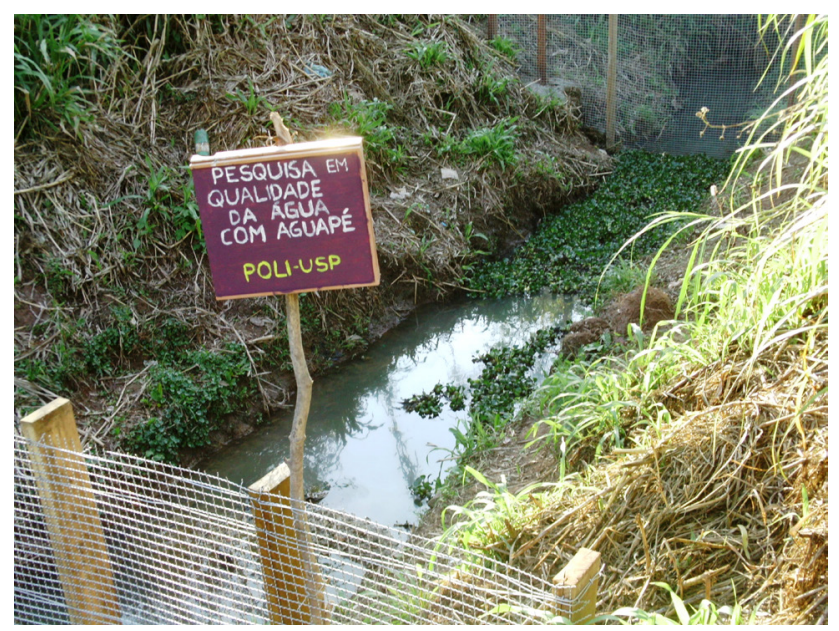

Figure 1 - Experiment 1 delimited by the grids upstream and downstream.

Both experiments were delimited by one grid upstream and one grid downstream, in order to avoid water hyacinth being carried away by the drift and solid waste to enter the parcel. The grids were made of galvanized steel, with $5 \mathrm{~cm} \times 5 \mathrm{~cm}$ sized wholes. They required periodic maintenance to prevent clogging by solid waste that reached the water course.

Both experiments had their water quality parameters monitored during the experiment once a month: the two samples were collected every time, one upstream and another downstream of the experiment, and they were used to evaluate the effect of the wetlands on water quality. A HANNA portable multiparameter, HI9828 model, was used to obtain the following data: Dissolved Oxygen (DO), $\mathrm{pH}$, temperature, electric conductivity and salinity. Laboratory analyses were conducted according to Standard Methods (Eaton et al., 1998), for the following parameters: True color, turbidity, total suspended solids (TSS), fixed suspended solids (FSS), volatile suspended solids (VSS), Biochemical Oxygen Demand (BOD), Total Kjeldahl Nitrogen (TKN), total phosphorus, total coliforms and fecal coliforms. The flow of the stream was measured with Water Flow Probe. When the flow was below the range of accuracy of the flow probe, the flow was considered equal to $2 \mathrm{~L} . \mathrm{S}^{-1}$.

Parameter results were compared to Brazilian legislation by the National Environmental Council (CONAMA), Resolution 357/2005, which classified water bodies and established water quality standards. Class 2 was used as a reference to comparison, since it includes waters destined to aquatic community protection and primary contact recreation, which are compatible uses for an urban park.

\section{RESULTS}

\section{Water hyacinth development}

Water hyacinth seedlings used on the first experiment showed a fast development in only two months, achieving heights of more than $35 \mathrm{~cm}$. Some plants flourished in that period, indicating that the plants were well adapted to the place. On the second experiment, adult specimens of macrophytes were used, and they didn't have a very healthy appearance. However, the plants survived pretty well; factors such as climate, hydrological regimen and nutrients probably helped.

In the first experiment, grids would often become clogged, due to waste accumulation. Combined with rain and floods typical from summer, clogging caused the grids to collapse. The second experiment's location was more positive, since it did not exhibit any of the problems related to waste disposal and flow increase existent in the first one. These problems drew attention to another big issue in the cities of developing countries, the correct solid waste disposal. 
Water courses characterization

Creek \#01 and Creek \#02 water quality data are presented in Table 1. In general, temperatures vary from 17,5 to $21^{\circ} \mathrm{C}$. DO values close to zero indicate that both water courses are not suitable for maintaining aquatic life, which would only be adequate above $5 \mathrm{mg} \cdot \mathrm{L}^{-1}$. Electrical conductivity values above $100 \mu \mathrm{S} . \mathrm{cm}^{-1}$ usually indicate impacted environments (CETESB, 2009), and conductivities observed in Creek \#02 (average of $1444 \mu \mathrm{S} . \mathrm{cm}^{-1}$ ) were much higher than observed in Creek \#01 (average of $333 \mu \mathrm{S} . \mathrm{cm}^{-1}$ ), which may indicate more polluted waters. Absence of DO two months in a row also confirms that statement. However, on further water quality parameters, Creek \#01 presented higher average and maximum values, especially in coliforms.

True color, turbidity and total phosphorus are in compliance with applicable legislation for both water courses, as shown in Table 1. BOD and TKN were above legislation levels in both creeks. Fecal coliforms overcame permitted value only in Creek \#01.

Table 1 - Water quality parameters of Tizo Urban Park's water courses.

\begin{tabular}{|c|c|c|c|c|c|c|c|c|}
\hline \multirow[b]{2}{*}{ Parameter } & \multirow[b]{2}{*}{ Unit } & \multicolumn{3}{|l|}{ Creek \#01 } & \multicolumn{3}{|l|}{ Creek \#02 } & \multirow{2}{*}{\begin{tabular}{|l} 
CONAMA \\
Resolutior \\
357
\end{tabular}} \\
\hline & & Variation & Average & $\begin{array}{l}\text { Standard } \\
\text { Deviation }\end{array}$ & Variation & Average & $\begin{array}{l}\text { Standard } \\
\text { Deviation }\end{array}$ & \\
\hline $\begin{array}{l}\text { Dissolved } \\
\text { Oxygen }\end{array}$ & $m g / L$ & $0-3,81$ & 2,16 & 1,59 & $0-2,57$ & 0,90 & 1,05 & 5 \\
\hline Conductivity & $\mu \mathrm{S} / \mathrm{cm}$ & $310-382$ & 333 & 25,39 & $\mid \begin{array}{l}898- \\
2107\end{array}$ & 1444 & 539,72 & \\
\hline$p H$ & - & $\begin{array}{l}6,62- \\
7,74\end{array}$ & 7,25 & 0,41 & $\begin{array}{l}7,25- \\
7,32\end{array}$ & 7,28 & 0,03 & 6 to 9 \\
\hline Temperature & ${ }^{\circ} \mathrm{C}$ & $\begin{array}{l}19,4- \\
21,3\end{array}$ & 20,2 & 0,68 & $\mid \begin{array}{l}17,53- \\
21,12\end{array}$ & 19,23 & 1,27 & \\
\hline Salinity & Ppt & $\begin{array}{l}0,15- \\
0,18\end{array}$ & 0,16 & 0,01 & $\begin{array}{l}0,44- \\
1,08\end{array}$ & 0,73 & 0,28 & \\
\hline True color & $\mathrm{CU}$ & $5-30$ & 20,5 & 11,66 & $7,5-20$ & 11,6 & 4,92 & 75 \\
\hline Turbidity & NTU & $9,2-15$ & 11,6 & 2,24 & $\mid \begin{array}{l}7,6- \\
22,5\end{array}$ & 12,6 & 5,83 & 100 \\
\hline$T_{S S^{1}}$ & $m g / L$ & $8-37$ & 20 & 9,70 & $8-50$ & 25 & 16,33 & \\
\hline$F S S^{2}$ & $m g / L$ & $4-18$ & 9 & 4,90 & $1-32$ & 16 & 13,46 & \\
\hline$V S S^{3}$ & $m g / L$ & $4-19$ & 11 & 5,11 & $2-18$ & 9 & 6,40 & \\
\hline$B O D^{4}$ & $m g / L$ & $6-18$ & 11 & 4,85 & $2-15$ & 9 & 5,45 & 5 \\
\hline$T K N^{5}$ & $m g / L$ & $4-28$ & 12 & 9,27 & $5-18$ & 12 & 4,66 & 3,7 \\
\hline $\begin{array}{l}\text { Total } \\
\text { Phosphorus }\end{array}$ & $m g / L$ & $\mid \begin{array}{l}0,09- \\
0,9\end{array}$ & 0,34 & 0,29 & $\begin{array}{l}0,07- \\
0,15\end{array}$ & 0,11 & 0,03 & 1 \\
\hline $\begin{array}{l}\text { Total } \\
\text { coliforms }\end{array}$ & $\begin{array}{l}M P N 100 \\
m L\end{array}$ & $\begin{array}{l}10100- \\
440000\end{array}$ & 165025 & 163454,13 & $\begin{array}{l}10000- \\
10100\end{array}$ & 10075 & 43,30 & \\
\hline $\begin{array}{l}\text { Fecal } \\
\text { coliforms }\end{array}$ & $\begin{array}{l}M P N / 100 \\
m L\end{array}$ & $\begin{array}{l}1060- \\
87000\end{array}$ & 20852 & 33132,32 & $\begin{array}{l}330- \\
1060\end{array}$ & 638 & 293,06 & 1000 \\
\hline \multicolumn{9}{|c|}{${ }^{1}$ Total Suspended Solids } \\
\hline \multicolumn{9}{|c|}{${ }^{2}$ Fixed Suspended Solids } \\
\hline \multicolumn{9}{|c|}{${ }^{4}$ Biological Oxygen Demand } \\
\hline${ }^{5}$ Total Kieldahl Nitr & rogen & & & & & & & \\
\hline
\end{tabular}




\section{Water monitoring results}

Figure 2 shows the evolution of DO concentration over the months of study. Downstream from the experiment there was a DO concentration reduction, indicating that aerobic processes were developed during organic matter degradation. On Experiment $\# 01$, oxygen reduction varied from $2 \%$ to $70 \%$, while on Experiment \#02, reduction was inexistent in most measurements. Reddy \& D'Angelo (1990) and Ho \& Wong (1994) obtained an average reduction significant in DO concentration with water hyacinth wetlands caused by microbial action.

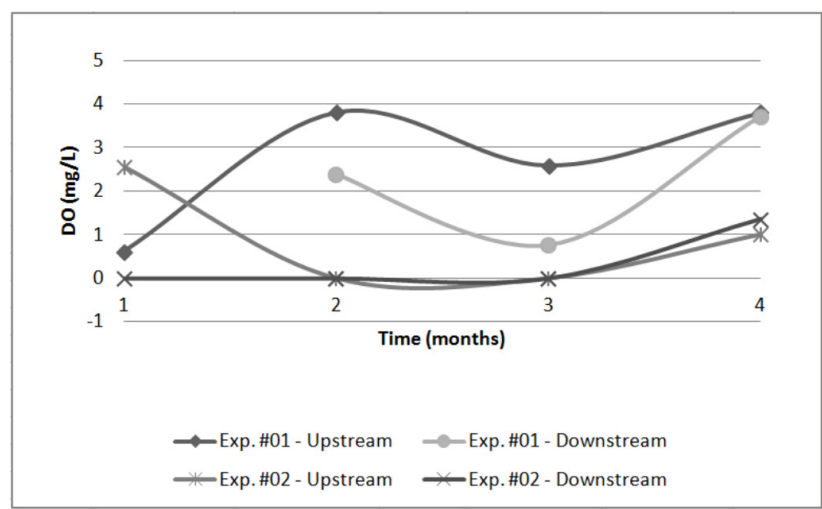

Figure 2 - Dissolved Oxygen values observed upstream and downstream, in both experiments.

Removal results are presented in Table 2. For BOD, maximum removal accomplished were $14 \%$ (Experiment \#01) and 36\% (Experiment \#02), from 14 to $9 \mathrm{mg} \cdot \mathrm{L}^{-1}$. Nevertheless, wetland participation wasn't enough to frame concerned water bodies to the $5 \mathrm{mg} \cdot \mathrm{L}^{-1}$ of BOD allowed by legislation. Ho \& Wong (1994) found an average BOD removal of $16,1 \%$ with initial values above $40 \mathrm{mg} \cdot \mathrm{L}^{-1}$.

True color, in general, was a well removed parameter. Maximum removal on Experiments \#01 and \#02 were $50 \%$ (from 5 to 2,5CU) and 75\% (from 20 to $5 \mathrm{CU}$ ), respectively. Experiment \#02 presented more consistent data, having a minimum removal of $25 \%$, on the third month. Turbidity was highly removed, which was credited to water hyacinth's capacity in retaining and removing suspended solids, since significant sedimentation was not observed on either creeks. Removal achieved was up to $54 \%$ (from 13 to 6 NTU) on Experiment \#01 and up to $73 \%$ (from 11 to 3NTU) on Experiment \#02. Akinbile \& Yusoff (2012) observed removals from $54,6 \%$ to $85,3 \%$ in turbidity, using water hyacinth for treating aquiculture wastewaters.

Experiment \#02 presented more elevated TSS concentrations, with removal of up to $76 \%$ (from 50 to $12 \mathrm{mg} . \mathrm{L}-1$ ), while Experiment \#01 had a maximum removal of $86 \%$ (from 21 to $3 \mathrm{mg} . \mathrm{L}-1$ ). Solids removal is important, once they can shelter bacteria and organic residues, besides settling in rivers beds and harming food supplier organisms (CETESB, 2009).

Table 2 - Water quality parameters concentration removals accomplished at each month, in percentage.

\begin{tabular}{|c|c|c|c|c|c|c|}
\hline \multirow{3}{*}{ Parameter } & \multicolumn{3}{|c|}{ Experiment \#01 } & \multicolumn{3}{|c|}{ Experiment \#02 } \\
\hline & October & November & December & May & June & July \\
\hline & 2012 & 2012 & 2012 & 2013 & 2013 & 2013 \\
\hline True color & 50,0 & 0 & 0 & 44,4 & 75,0 & 25,0 \\
\hline Turbidity & 23,3 & 53,8 & 8,7 & 70,7 & 72,7 & 18,4 \\
\hline$T S S^{1}$ & 64,9 & 85,7 & 25,0 & 76,0 & 37,5 & 46,2 \\
\hline$F S S^{2}$ & 83,3 & 90,0 & 50,0 & 81,3 & 75,0 & $-500,0$ \\
\hline$V S S^{3}$ & 47,4 & 81,8 & 0 & 66,7 & 0 & 91,7 \\
\hline$B O D^{4}$ & 4,1 & 14,3 & 0 & 35,7 & 16,7 & 33,3 \\
\hline$T K N^{5}$ & $-10,7$ & 25,0 & $-40,0$ & 23,1 & 22,2 & 60,0 \\
\hline Total P & 11,1 & 50,0 & 50,0 & 28,6 & $\begin{array}{l}- \\
700,0\end{array}$ & 33,3 \\
\hline Total & & & & & & \\
\hline coliforms & 0 & 84,1 & 0 & 0 & 0 & 0 \\
\hline $\begin{array}{l}\text { Fecal } \\
\text { coliforms }\end{array}$ & 51,2 & 58,3 & 22,4 & 56,6 & 17,9 & 69,4 \\
\hline $\begin{array}{l}\text { Flow water } \\
\left(L . s^{-1}\right)\end{array}$ & 5,22 & 3,67 & 3,12 & 2 & 2 & 2 \\
\hline $\begin{array}{l}\text { Total Suspendec } \\
{ }^{2} \text { Fixed Suspende } \\
3 \text { Volatile Suspend } \\
4{ }^{4} \text { Biological Oxyge } \\
{ }^{5} \text { Total Kieldahl Ni }\end{array}$ & $\begin{array}{l}\text { ids } \\
\text { ids } \\
\text { idlids } \\
\text { olids } \\
\text { mand }\end{array}$ & & & & & \\
\hline
\end{tabular}

According to Rijn (1984), the ratio of the suspended load and the total load is greater than 0,8 when the ratio of the bed-shear velocity and particle fall velocity is greater than two, for flat bed, low flow regime, width-depth ratio larger than three and bed median particle sizes smaller than about $450 \mu m$ conditions.

In the flow conditions observed on present experiments, in which the depth flow averaged $0,15 \mathrm{~m}$, the average flow velocity was less than $0,04 \mathrm{~m} . \mathrm{s}^{-1}$ and width-depth ratio was greater than four; sedimentation would, therefore, be very low without water hyacinth. The observed removal of turbidity and TSS shows that plants influenced the sedimentation and absorption of particles in suspension.

TKN presented negative removal in two measurements on Experiment \#01, and a removal of $25 \%$ on the second month, which is not significant, from 4 to $3 \mathrm{mg} \cdot \mathrm{L}^{-1}$. On Experiment \#02 removals were more significant: from 13 to $10 \mathrm{mg} . \mathrm{L}^{-1}(23 \%)$ in May, from 18 to $14 \mathrm{mg} \cdot \mathrm{L}^{-1}(22 \%)$ in June and from 5 to $2 \mathrm{mg} \cdot \mathrm{L}^{-1}(60 \%)$ in July (Table 2). Akinbile \& Yusoff (2012) obtained removals that varied from $10,7 \%$ to $85,7 \%$ for TKN, in a four-week period, using water hyacinth. Ho \& Wong (1994) observed average removals of $6,5 \%$ in TKN 
and 5,8\% in Total Phosphorus, also using water hyacinth in two experiments of 21-22 days each. For Total Phosphorus, removals of up to $50 \%$ were observed twice in Experiment \#01, and up to 33\% on Experiment \#02. Besides Phosphorus removals were satisfactory, the values were already low and concentrations were not highly affected: from 0,2 to $0,1 \mathrm{mg} \cdot \mathrm{L}^{-1}$ (Experiment \#01) and from 0,15 to 0,1 mg. L-1 (Experiment \#02).

Concerning total coliforms, removal was observed only once, when a value of $440000 \mathrm{MPN} / 100 \mathrm{~mL}$ was reduced to $70000 \mathrm{MPN} / 100 \mathrm{~mL}\left(84 \%\right.$ or $\left.0,8 \log _{10}\right)$, on Experiment \#01. Ho \& Wong (1994) verified an average removal of $42 \%$ of total coliforms using water hyacinth. For fecal coliforms, were observed removals from $0,1(22 \%)$ to $0,38 \log _{10}(58 \%)$ on Experiment \#01 and removal from $0,09(18 \%)$ to $0,51 \log _{10}(69 \%)$ on Experiment \#02. Those results are very positive, as fecal coliforms are interest compounds for recreation, and its removal can represent a sanitary reliability for park visitors.

\section{DISCUSSION}

Obtained results are not statistical, since there were only three measurements for each experiment. An extensive monitoring is needed to confirm the real efficacy of physical, chemical and biological parameters removal by flowing water wetlands. Yet, maximum removals obtained were coherent with what was observed in consulted literature for most parameters. Therefore, punctual samples indicated the decontamination potential of water hyacinth wetlands, even with little contact time between water and plants.

Experiments development has demonstrated that water hyacinth adapted well to the conditions offered at Tizo Park; probably due to high solar incidence, water and nutrients availability. Adaptation easiness is a great advantage to wetlands installation. Water hyacinth being an abundant native plant avoids the introduction of exotic species, which could unbalance the native ecosystem. Solid waste contribution from surroundings impaired the experiments. Grids used to contain floating plants in the desired creek portion also need to be improved to avoid clogging. Testing alternatives like floating barriers, dikes and others is encouraged to best adapt to the landscape. It's also noteworthy that wetlands can bring benefits to parks relating to habitat and refuge for native species, and environmental education activities for the local population.

From all monitored water quality parameters, turbidity, true color and TSS presented elevated maximum removal (above 70\% in Experiment \#02). Most probably removal mechanisms for these parameters were physical, thanks to the extensive and fibrous roots from water hyacinths. TKN, Total Phosphorus and fecal coliforms presented satisfactory maximum removal (above $50 \%$ in at least one of the experiments). BOD presented less significant maximum removals, of only $36 \%$, and total coliforms only presented removal once, although high (84\%). Due to observed inconsistencies and short monitoring time, water analysis results aren't conclusive, and equal or higher removals in further studies cannot be guaranteed. Nevertheless, the fact that removals, when present, were similar to those registered in consulted literature cannot be ignored, and show that wetlands may have water purifying effects even with short contact time.

Water hyacinth planting for polluted natural water treatment can be a viable solution for parks with degraded water resources. In ecological and esthetical terms, the study has shown to be extremely positive, except for the grids - a better alternative should be studied. Concerning sanitary aspects, results indicate probable feasibility. Specifically for Tizo Park, it is believed that wetland water treatment can be accomplished by creating an artificially flooded ecosystem, using impacted plain areas to recover the environment and allow more significant chemical and biological removal processes.

\section{REFERENCES}

Akinbile, C.O. \& Yusoff, M.S. 2012. Assessing water hyacinth (Eichhornia Crassopes) and lettuce (Pistia Stratiotes) effectiveness in aquaculture wastewater treatment. Int J Phytorem. 14(3):201-211.

Brix, H. 1997. Do macrophytes play a role in constructed treatment wetlands? Wat Sci Tech. 35(5):11-17.

Campbell, C.S. \& Ogden, M.H. 1999. Constructed Wetlands in the Sustainable Landscape. New York: John Wiley \& Sons, Inc.

[CETESB] Companhia Ambiental do Estado de São Paulo 2009. Qualidade das águas interiores no Estado de São Paulo: Significado ambiental e sanitário das variáveis de qualidade das águas e dos sedimentos e metodologias analíticas de amostragem (Apêndice A). São Paulo.

Costa, R. 2006. Impactos sobre remanescentes de florestas de Mata Atlântica na Zona Oeste da Grande São Paulo: um estudo de caso da mata da Fazenda Tizo. Dissertação de mestrado. Universidade de São Paulo - USP, São Paulo. $211 \mathrm{p}$.

Dhote, S. \& Dixit, S. 2009. Water quality improvement through macrophytes - a review. Environ Monit Assess. 152:149-153. 
Eaton, A. D., Clesceri, L. S., Greenberg, A. E., Franson, M. A. H., American Public Health Association, American Water Works Association \& Water Environment Federation 1998. Standard Methods for the Examination of Water and Wastewater. 20th ed., Washington (D.C.): American Public Health Association.

Ho, Y.B. \& Wong, W. 1994. Growth and macronutrient removal of water hyacinth in a small secondary sewage treatment plant. Resour Conserv Recycl. 11:161-178.

Kivaisi, A.K. 2001. The potential for constructed wetlands for wastewater treatment and reuse in developing countries: a review. Ecol Eng. 16:545-560.

Monteiro, R.C.M. 2009. Viabilidade técnica do emprego de sistemas tipo "wetlands" para tratamento de água cinza visando o reúso não potável. Dissertação de Mestrado. Universidade de São Paulo - USP, São Paulo. 84 p.

Penfound, W.T. \& Earle, T.T. 1948. The biology of the water hyacinth. Ecol Monogr. 18(4):447-472.
Reddy, K.R. \& D'Angelo, E.M., 1990. Biomass yeld and nutrient removal by water hyacinth (Eichhornia crassipes) as influenced by harvesting frequency. Biomass. 21:27-42.

Rijn, L.C. van. 1984. Sediment transport, part II: suspended load transport. J. Hydrauli. Eng. 110(11): 1613-1641.

Silva, R.T. \& Porto, M.F.A. 2003. Gestão urbana e gestão das águas: caminhos da integração. Estud. Av.. São Paulo, 17(47):129-145.

Shutes, R.B.E., 2001. Artificial wetlands and water quality improvement. Environ Int. 26:441-447.

Stottmeister, U.; Weisner, A.; Kuschk, P.; Kappelmeyer, U.; Kästner, M.; Bederski, O.; Müller, R. A.; Moorman, H. 2003. Effects of plants and microorganisms in constructed wetlands for wastewater treatment. Biotechnol Adv. 22:93-117.

Welsch, D.J.; Smart, D. L.; Boyer, J. N.; Minkin, P.; Smith, H. C.; McCandless, T. L. 1995. Forested Wetlands: Functions, Benefits and the Use of Best Management Practices. United States Department of Agriculture Forest Service.

Submetido: Maio/2015

Revisado: Agosto/2016

Aceito: Setembro/2016 